\title{
Mechanical pretreatment of lignocelluloses for enhanced biogas production: Methane yield prediction from biomass structural components
}

\author{
S.O Dahunsi ${ }^{\mathrm{a}, \mathrm{b}, *}$ \\ ${ }^{a}$ Faculty of Environment and Labour Safety, Ton Duc Thang University, Ho Chi Minh City, Viet Nam \\ ${ }^{\mathrm{b}}$ Biomass and Bioenergy Group, Environment and Technology Research Cluster, Landmark University, Nigeria
}

\section{A R T I C L E I N F O}

\section{Keywords:}

Anaerobic digestion

Biogas

Biomass

Microorganisms

Pretreatment

Silage

\begin{abstract}
A B S T R A C T
In this study, mechanical pretreatment was applied to six different lignocelluloses in two different treatment phases and the prediction of their methane yield was done from biomass chemical composition. Physicochemical, proximate and microbial analyses were carried out on both pretreated and untreated biomass using standard methods. Mechanical pretreatments caused the breakdown of structural materials in all the used biomass which was characterized by reduction of the lagging time during anaerobic digestion and the subsequent increase in methane yield up to $22 \%$. The different loading rate of biomass had no effect on the overall methane yield increase. Both single and multiple linear regressions models were used in order to correlate the chemical composition of the biomass with their methane potentials and a fairly high correlation $\left(\mathrm{R}^{2}=0.63\right)$ was obtained. The study also showed that the pretreatments are economically feasible. Therefore, its further application to other biomass is encouraged.
\end{abstract}

\section{Introduction}

Lignocellulosic biomass forms the major organic component of the earth's vegetation cover and they are generally regarded as profound feedstock for renewable and sustainable biofuels production (Faostat, 2016). The conventional practice of biomass burning is not environmentally friendly in that in contribute majorly to the incidence of environmental pollutions in the areas of global warming and climate change. Therefore, the bioconversion of lignocelluloses to biofuels such as biogas, bioethanol, biodiesel and others has several environmental benefits including $\mathrm{CO}_{2}$ neutrality and reduction of emissions (Hayashi et al., 2014). Anaerobic digestion is one of the efficient technologies for biofuels production but it is undoubtedly the most promising due to its energetic potentials over liquid biofuels (Dahunsi et al., 2017a,b).

However, the structural make-up of lignocellulosic biomass make them less suitable as substrates for anaerobic digestion. They are mostly with different shapes, sizes, moisture contents and varied levels of lignin, cellulose, hemicellulose and fixed solids (Venturin et al., 2018). Besides, this composition of lignocelluloses brings about the rate limiting phenomenon during the hydrolysis stage of anaerobic digestion as the hydrolytic microbes take ample time to enzymatically degrade the biomass due to their complex inherent properties (Tsapekos et al., 2018). For these reasons, there is need to pretreat lignocelluloses before they are introduced into the anaerobic digester in order to overcome the possible operational challenges that usually arise prominent among which is clogging, floating layers and recalcitrance of solid to enzymatic breakdown (Katukuri et al., 2017).

Several pretreatment methods have been experimented on several biomass with different outcomes in terms of biomass deconstruction and ultimate biogas/methane yield. These include mechanical, physical, chemical, biological and combined pretreatment methods. Mechanical pretreatment is one of the famous methods which has been reported to possess the capacity to efficiently improve the inherent features of lignocellulosic biomass by reducing their sizes, disrupting their surface configurations among others (Tsapekos et al., 2017a). Another advantage of this method is that it is the most suitable for industrial applications (Carrere et al., 2015). Biomass deconstruction using mechanical method is usually via the application of shear and/or compression forces which is equally a function of the materials used in the construction of the comminution device. As a matter of fact, the coarseness or smoothness of material used for the construction of a comminution device goes a long way to either retard or improve the efficiency of biogas production from a lignocellulosic material (Tsapekos et al., 2015).

Furthermore, the characteristics of a particular lignocellulosic biomass is of great importance in determining the efficiency of pretreatment in order to achieve higher bioenergy yield (Dahunsi et al., $2018 \mathrm{a}, \mathrm{b})$ as the success of most biomass' biodegradability is a function

\footnotetext{
*Address: Faculty of Environment and Labour Safety, Ton Duc Thang University, Ho Chi Minh City, Viet Nam.

E-mail address: dahunsi.olatunde.samuel@tdtu.edu.vn.
} 
of the cell wall composition especially in terms of lignin content. This is why in most cases, ensiled biomass are often preferred for high methane production mainly because the carbohydrates content of such biomass have been previously fermented into intermediate acids such as lactic acid while the biomass was being ensiled. In the current energy literature, there is a well-established correlation between the characteristics of lignocellulosic biomass and their biodegradability, whereas there is no such relationship between biomass chemical composition and their methane potential (Dandikas et al., 2015) which is a source of tangible information about the biodegradability of a biomass (Charnier et al., 2016; Fitamo et al., 2017; Dandikas et al., 2018; Edwiges et al., 2018).

Another important aspect of mechanical pretreatment is the durability and robustness of equipment which ensures the overall success of the process in the long run and which is equally important to avoid damage or deterioration of equipment during real-life applications. This is because mechanical pretreatment equipment are prone to damage when they erroneously handle large materials such as stones and metals instead of the target materials i.e. lignocellulosic biomass. There is therefore need to control and optimize the operation of mechanical pretreatment machines as this would immensely reduce the energy input while also increasing their output in handling lignocelluloses prior to anaerobic digestion process (Tsapekos et al., 2017a,b). Herrmann et al. (2012) has earlier reported that the type of comminution equipment used in a machine determines the energy balance of anaerobic digestion process treating different biomass. This therefore calls for the adoption of appropriate technology in the design of equipment for mechanical pretreatment of biomass so as to enhance substrate's biodegradability.

Therefore, this study aimed at evaluating the efficacy of two mechanically-based approaches of pretreating three different grasses: Elephant grass (Pennisetum purpureum), Wild Mexican Sunflower (Tithonia diversifolia) and Siam weed (Chromolaena odorata) for the purpose of enhancing methane production. Performance of the pretreatment was based on the different speeds of rotation and loading of biomass. The choice of the three grasses was due to their huge availability in most marginal lands and they all serve as stubborn weeds of crops in most cropping systems of the world. Besides, these grasses are of low fodder value and are therefore of little use but rather constitute environmental challenges which forms the basis for their usage as biofuel biomass. This study further evaluated the correlation between the chemical characteristics of these biomass and their methane yield in order to develop substantial model for predicting their biodegradability. Finally, due to the importance of using an efficient prediction tool in the assessment of the energy output from a biogas generating plant using lignocelluloses, a robust model was developed in this study taking into accounts datasets from the different biomass.

\section{Materials and methods}

\subsection{Inoculum}

The inoculum used in this study was obtained from the digestate of a running mesophilic biogas digester within the campus. After collection, it was immediately transported to the Microbiology laboratory and carefully sorted in order to get rid of particles which exceed $10 \mathrm{~mm}$ in size and was thereafter incubated for 10 days at mesophilic temperature so as to remove background methane production. Analysis of the inoculum showed the physicochemical constituent to be: $\mathrm{pH}$ of 7.98 , total solids of $21.9 \pm 0.2 \mathrm{~g} / \mathrm{L}$, volatile solids of $14.2 \pm 0.1 \mathrm{~g} / \mathrm{L}$, total Kjeldahl Nitrogen of $4.4 \pm 0.1 \mathrm{~g}-\mathrm{TKN} / \mathrm{L}$, ammonium nitrogen of $3.3 \pm 0.1 \mathrm{~g} \mathrm{NH}_{4}^{+}-\mathrm{N} / \mathrm{L}$, and total volatile fatty acids of $0.8 \pm 0.1 \mathrm{~g} / \mathrm{L}$.

\subsection{Biomass selection and preparation}

In order to achieve the aim of defining the relationship between the chemical composition of lignocellulosic biomass and their methane potentials, three typical lignocellulosic plants were selected which are: Elephant grass (Pennisetum purpureum), Wild Mexican Sunflower (Tithonia diversifolia) and Siam weed (Chromolaena odorata). All samples were collected from the Teaching and Research Farm of Landmark University, Omu-Aran, Kwara State, Nigeria and were transported to the Environmental Engineering Laboratory where the study was performed. In all, two varieties of Elephant grass i.e. Morado and King grass were selected; three varieties of Sunflower i.e. Tithonia diversifolia, Tithonia rotundifolia and Tithonia tubiformis were selected while only one variety of Siam weed i.e. Chromolaena odorata was selected making a total of six different biomass types used in this study. In order for the biomass to be ensiled, they were all kept at room temperature $\left(25^{\circ} \mathrm{C}\right)$ for two days for partial drying after which they were kept in sealed plastic bags under anaerobic conditions devoid of any biological additives/preservative over a period of sixty days. At the end of the fermentation process, all samples were milled to size of $2 \mathrm{~mm}$ and their chemical compositions were determined.

\subsection{Biomass pretreatment}

The evaluation of mechanical pretreatment for all the biomass used in this study was carried out in two phases based on the structures of the comminuting apparatus so that their impact on the biomass' biodegradability can be evaluated. The first phase involved the use of a machine equipped with a plastic sweeping brush rotating at different driving speeds placed diametrically opposed to a steel mesh conditioner so that the plastic brush roller will vehemently exert pressure on the biomass and move it towards the equipment that is rotating in a reserve manner. The steel roller on the other hand was constantly rotating in the same speed so as to continuously convey the biomass towards the brush roller. The movement of the biomass to the pretreatment unit was made easy via a conveyor belt moving at the driving speed of a mover in a real life situation i.e. $10 \mathrm{~km} / \mathrm{h}$. This was done so as to mimic a large scale pretreatment procedure. The second pretreatment phase was a little different from the first in that a corrugated roller with surface made of coarse steel was made to rotate towards a stable coarse shell so as to enhance the deconstruction done to the surface of biomass. In both treatments, a total of $1.8 \mathrm{~kg} / \mathrm{m}^{2}$ biomass was treated which was meant to simulate the same process for a full-scale harvesting machine in a conventional Tithonia diversifolia field (Tsapekos et al., 2018). Besides, the operation was also carried out at different loads using different quantities of biomass.

\subsection{Biochemical methane potentials (BMP) test and batch digestion}

The biochemical methane potential test was carried out based on the best responses from the pretreatments of the biomass. The BMP tests were carried out with the aid of $250 \mathrm{~mL}$ batch reactors attached to $500 \mathrm{~mL}$ eudiometer tubes in triplicates for each sample with $10 \%$ (m.v ${ }^{-1}$ ) volatile solids at mesophilic temperature i.e. $37^{\circ} \mathrm{C}$ following the VDI standards 4630 (2006). Record of biogas production was taken until stability was achieved when the daily biogas yield was $\leq 1 \%$ of the total biogas production in the experiment. The batch anaerobic digestion of each biomass (Pretreated and untreated) was thereafter carried out using a chain of the Computer controlled anaerobic digester (EDIBON) was used in this experiments.

\subsection{Analytical methods}

\subsubsection{Proximate characterization of biomass}

The standard method for analysis of water and wastewaters (APHA, 2012) was used in determining the concentrations of total and volatile solids in all samples (Pretreated and untreated). For the measurement of $\mathrm{pH}, 1 \mathrm{~g}$ of each sample was dissolved in $20 \mathrm{~cm}^{3}$ of water and was incubated at $25^{\circ} \mathrm{C}$ for a period of $30 \mathrm{~min}$ and the supernatant was used 
for $\mathrm{pH}$ measurement using the HI $2211 \mathrm{pH} / \mathrm{ORP}$ Meter electrode (Hanna Instruments, Germany). A TOC analyzer (SSM-5000A Shimadzu, Japan) was employed in the determination of total organic carbon (TOC) content of all samples while the total Kjeldahl nitrogen (TN) was determined by using a standard Kjeldahl method. Determination of phenolics was done with the aid of an ultra-high performance liquid chromatography (Nexera XR, Shimadzu, Japan) (Planinić et al., 2016). Concentrations of volatile fatty acids (VFAs) were determined using standard method earlier described (Panjičko et al., 2017).

\subsubsection{Structural characterization of biomass}

The structural composition of all pretreated and untreated samples was determined. In doing this, the content of major structural components such as lignin, cellulose, hemicellulose and arabinan were determined using a standard method (Sluiter et al., 2008). Similarly, the extractable materials in the different samples of the biomass were determined via extraction in a Soxhlet extractor for $6 \mathrm{~h}$ whereas; samples were burnt in a muffle furnace in order to determine the concentration of fixed solids following the method of Sluiter et al. (2008).

In determining the contents of the structural materials, the dried sample $(0.3 \mathrm{~g})$ was treated with $3 \mathrm{~mL}$ of $72 \%$ sulfuric acid $\left(\mathrm{v} . \mathrm{v}^{-1}\right)$ in a thermostatic bath at a temperature of $30^{\circ} \mathrm{C}$ for $1 \mathrm{~h}$ and the resulting filtrate was used for the determination of carbohydrate (Sluiter et al., 2012). The liquid chromatography coupled with mass spectrometer (LC-MS) (SHIMADZU, Japan) operated with AMINEX ${ }^{\circledast}$ BIORAD HPX87H column in refractive index detector (DIR-10A) was used to analyze carbohydrates. The mobile phase in this analysis was 0.005 mol. $\mathrm{L}^{-1}$ sulfuric acid in an isocratic mode, at $45^{\circ} \mathrm{C}$, with an injection volume of $20 \mu \mathrm{L}$ and flow of $0.6 \mathrm{~mL} \cdot \mathrm{min}^{-1}$. Calibration curves were used to finally determine the concentrations of the compounds using specific LC-MS standards (Bazoti et al., 2017).

For the concentration of furfural and hydroxymethylfurfural, the same LC-MS described above was used but in this case was equipped with a diode array detector (DAD) and operated with C18 column. In this, the mobile phase was 1:8 acetonitrile/water to which $1 \%$ acetic acid was added, and the experiment carried out at an oven temperature of $30^{\circ} \mathrm{C}$ in an isocratic mode with an injection volume of $20 \mu \mathrm{L}$ and flow of $0.8 \mathrm{~mL} \cdot \mathrm{min}^{-1}$. Calibration curves were subsequently used to determine the concentration of the compounds. All samples were analyzed in triplicates.

\subsection{Assessment of economic viability of pretreatments}

There is a need to establish the economic viability of pretreatment in order to justify the investment into the procurement of acid and alkali besides the cost of obtaining energy used for the pretreatment. In doing this, the balance between production and usage of energy was done by comparing the cost of obtaining thermal energy with the additional energy that will be obtained from the additional biogas as a result of the applied pretreatments. The purpose was to evaluate the possibility that the extra biogas obtained would suffice for the cost of thermal energy. The thermal energy required (TER) for pretreating each biomass was determined via Eq. (1):

$\mathrm{TER}=\frac{m \times S h * \text { Tfinal }- \text { Tinitial }}{3600}$

where:

$$
\begin{aligned}
& m=\text { mass substrate }(1000 \mathrm{~kg}) \\
& S h=\text { specific heat of water } \\
& T=\text { Temperature }
\end{aligned}
$$

\subsection{Analysis of microbial community}

In order to analyze the microbial community, $45 \mathrm{~mL}$ each was taken from all samples and effluents on days $6,12,18,24$ and 30 respectively and stored at $-20^{\circ} \mathrm{C}$. The total DNA extraction from all samples was done according to the method of Vilchez-Vargas et al. (2013) followed by conventional PCR in order to target the total bacterial population using the total bacterial primers P338f and P518r (Boon et al., 2002). Agarose gel electrophoresis was thereafter used to evaluate the purity of the extracted DNA and PCR products which was followed by Real-time PCR analysis using a StepOnePlus ${ }^{\mathrm{TM}}$ Real-Time PCR System (Applied Biosystems, Carlsbad, CA). The total bacterial population was then analyzed (Desloover et al., 2015). The quality of the Real-time PCR products was checked by examining the different parameters which were obtained with the StepOnePlus software V2.3. Analysis of each sample was done in triplicate.

\subsection{Analysis of data}

Assessment of the possible effect that the pretreatments may have on the kinetics of the biomass' degradability during the digestion process in this study was done with the Gompertz equation as modified below:

$S(t)=M_{0} \times \exp \left\{-\exp \left[\frac{\mathrm{Rmax} \times \mathrm{e}}{M 0}(X-t)+1\right\}\right.$

where:

$S(t)=$ cumulative yield of methane at time $t\left(\mathrm{mLCH}_{4} / \mathrm{g} \mathrm{VS}\right)$,

$M_{O}=\mathrm{CH}_{4}$ yield (mL/gVS),

$R \max =$ maximum $\mathrm{CH}_{4}$ production rate $(\mathrm{mL} / \mathrm{gVS} / \mathrm{d})$,

$\chi=$ lag phase (day),

$e=$ Euler's constant (2.7183).

In doing this, the accuracy of prediction of the models used was measured using the determination coefficient $\left(\mathrm{R}^{2}\right)$ and the root mean square error (RMSE) (Tsapekos et al., 2015). This was followed by the determination of statistical significance differences among the mechanically pretreated and untreated samples using Tukey post hoc test at $95 \%$ confidence interval $(\mathrm{p}<0.05)$ and one-way ANOVA. The Graphpad Prism (Graphpad Software, Inc., San Diego, CA) was used in this testing. After this, the normal distribution of the samples was evaluated using the Kolmogorov-Smirnov test at 95\% confidence interval ( $\mathrm{p}<0.05$ ). The correlation among the chemical components of biomass was determined by descriptive statistics. Also, the prediction of methane yield from all biomass was done by multiple linear regression analysis. In order to ensure accuracy of the prediction, calculation of the coefficient of variation (CV) and normalized root mean square error (NRMSE) were also carried out using the XLSTAT software (Addinsoft, New York, NY).

\section{Results and discussion}

\subsection{Biomass characteristics before and after pretreatments}

The structural characteristics of all biomass used in this study before and after pretreatments is shown in Table 1. From the table, the composition of total lignin in the untreated biomass samples was between 27.2 and $40.6 \% \mathrm{~m} . \mathrm{m}^{-1}$ with the highest found in Chromolaena Odorata while the lowest was found in Tithonia tubiformis. For cellulose, the composition was between $26.6 \% \mathrm{~m} . \mathrm{m}^{-1}$ for Pennisetum purpureum (Morado) and $36.4 \% \mathrm{~m} . \mathrm{m}^{-1}$ for Tithonia diversifolia. For hemicellulose composition in the untreated biomass, the lowest $\left(9.8 \% \mathrm{~m} . \mathrm{m}^{-1}\right)$ was found in Pennisetum purpureum (Morado) while the highest $(12.4 \%$ $\mathrm{m} . \mathrm{m}^{-1}$ ) was found in Chromolaena odorata. For araninan, the lowest composition $\left(3.4 \% \mathrm{~m} . \mathrm{m}^{-1}\right)$ was recorded for Pennisetum purpureum (King grass) while the highest $\left(5.4 \% \mathrm{~m} . \mathrm{m}^{-1}\right)$ was found in Tithonia tubiformis. Protein composition of all the biomass was highest in Chromolaena odorata with $4.8 \% \mathrm{~m} . \mathrm{m}^{-1}$ while the lowest composition $(2.2 \%$ $\mathrm{m} . \mathrm{m}^{-1}$ ) was found in Pennisetum purpureum (Monado). These results are very similar to the findings of Cai et al. (2016), who analyzed the structural component of corn stalk and reported values of 21.4, 43.4 


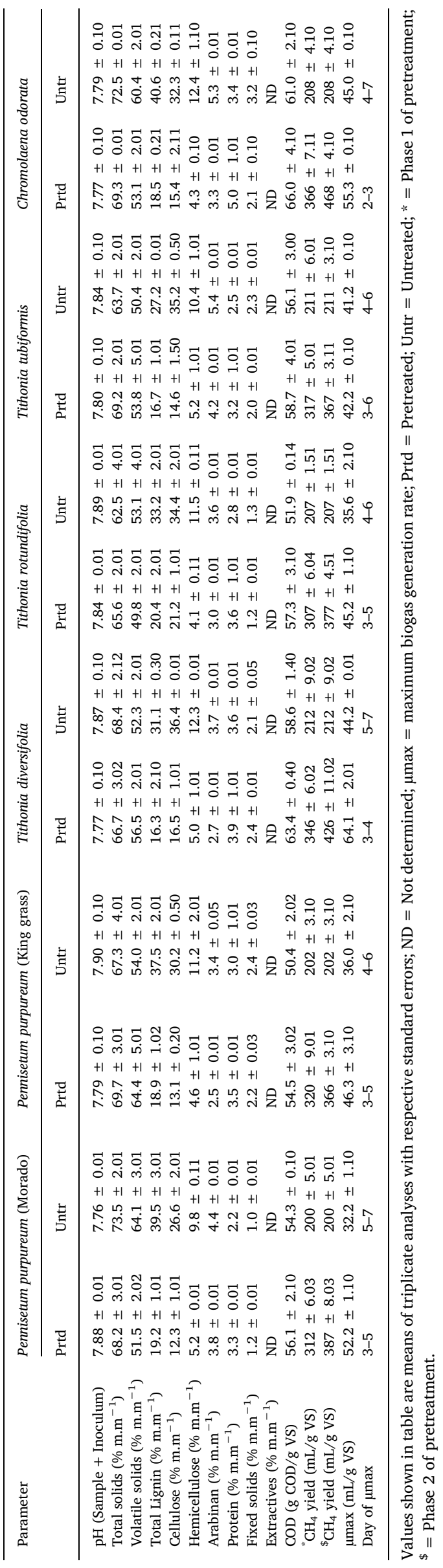

and $19.5 \%$ for lignin, cellulose and hemicellulose respectively. Similarly, Li et al. (2016), reported the values of 20,34 and $24 \%$ for lignin, cellulose and hemicellulose respectively from the structural analysis of the different parts of corn stalk.

After the application of mechanical pretreatment to all the biomass in this study, there was reduction in the composition of all four structural materials i.e. lignin, cellulose, hemicellulose and arabinan. However, the protein contents increased in all samples but at different rates. For lignin composition of the pretreated biomass, there was reduction of 51,50, 48, 39, 40 and 54\% for Pennisetum purpureum (Monado), Pennisetum purpureum (King grass), Tithonia diversifolia, Tithonia rotundifolia, Tithonia tubiformis and Chromolaena odorata respectively. For cellulose composition, reductions of 54, 57, 55, 38, 59 and $52 \%$ were recorded for Pennisetum purpureum (Monado), Pennisetum purpureum (King grass), Tithonia diversifolia, Tithonia rotundifolia, Tithonia tubiformis and Chromolaena odorata respectively. For the composition of hemicellulose in all six biomass after pretreatment, there were reductions of $47,60,59,64,50$ and $65 \%$ respectively while the composition of arabinan reduced by $14,26,27,17,22$ and $38 \%$ respectively in all six biomass. The protein content of all biomass increased after the pretreatment which indicate the breakdown of complex molecules of amino acids into their hydrolysable derivatives. The increase in value was 33, 14, 8, 22, 22 and $32 \%$ for Pennisetum purpureum (Monado), Pennisetum purpureum (King grass), Tithonia diversifolia, Tithonia rotundifolia, Tithonia tubiformis and Chromolaena odorata respectively.

Table 2 shows the proximate composition of both pretreated and untreated samples of all the biomass used in this study. It can be deduced from the table that all the biomass contains appreciable level of nutrients elements and minerals needed for the survival and microbial metabolism in a fermentation medium such as anaerobic digestion. Across all six biomass, there is high composition of important nutrient elements such as carbon, nitrogen, phosphorus, potassium, calcium, and magnesium all of which were highest in the raw biomass of Tithonia diversifolia and lowest in Pennisetum purpureum (Monado). After the mechanical pretreatment, the levels of all these nutrient elements increased signifying that the action of the pretreatment methods brought about the tenderization of the biomass thereby yielding up the nutrient that were initially locked up in the cells of the biomass. After pretreatment, the Tithonia diversifolia was still the richest in terms of nutrients and elemental composition while Pennisetum purpureum (Monado) remained the least. In some previous research, application of pretreatments have been reported to increase the nutrient composition of lignocellulosic biomass which are known to be composed of numerous nutrients but which are locked up in their tissues majorly due to their complex nature in terms of the lignin-cellulose-hemicellulose matrix (Dahunsi et al., 2017c,d,e,f). (See Table 3).

\subsection{Result of BMP test}

Table 1 also shows the methane yields from all samples (Pretreated and untreated). In the phase of mechanical pretreatment, methane yield of between 312 and $366 \mathrm{~mL} / \mathrm{g}$ VS were obtained from the six biomass. The highest yield was achieved at the brush speed rotation of $800 \mathrm{rpm}$ while there was significant difference $(p>0.05)$ in other methane yield values when compared with the untreated operations. This finding agrees with the study carried out by Tsapekos et al. (2018) who reported a negative proportional correlation between the biodegradability of biomass and the speed of machine employed for harvesting. However, the same authors have earlier reported a positive correlation between biomass biodegradability and machine speed as a sure means to achieve breakdown of biomass' structural components (Tsapekos et al., 2017a,b). Much earlier, other authors have suggested that pretreatment efficiency is not directly proportional to machine's rotational speed but a function of the type of technology or implement used for disruption (Boscaro et al., 2015). 


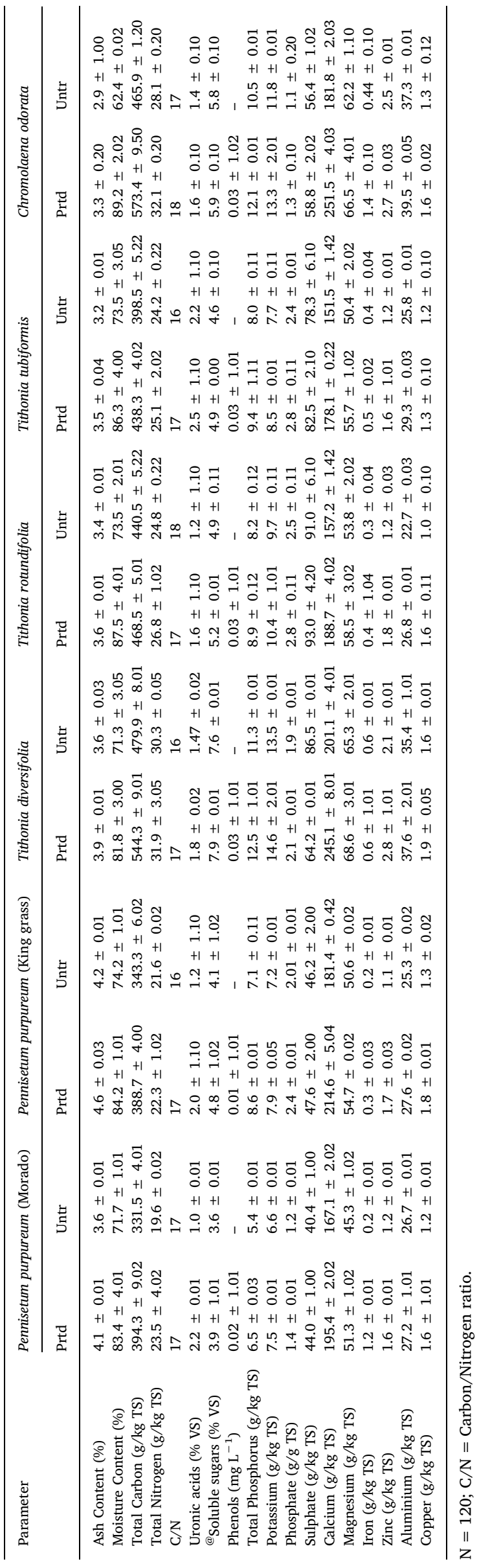

Table 3

Effects of mechanical pretreatments and kinetics.

\begin{tabular}{|c|c|c|c|c|c|c|c|}
\hline \multirow[t]{2}{*}{ Phase One } & \multicolumn{7}{|c|}{ Road sweeping brush against crimper } \\
\hline & Brush (rpm) & $\begin{array}{l}\text { Crimper } \\
\text { (rpm) }\end{array}$ & $\begin{array}{l}\mathrm{CH} 4 \text { yield } \\
\text { (mL/g VS) }\end{array}$ & $\begin{array}{l}\mathrm{R}_{\max } \\
(\mathrm{mL} / \mathrm{g} \\
\mathrm{VS} / \mathrm{d})\end{array}$ & $\chi d$ & $\mathrm{R}^{2}(\%)$ & RMSE \\
\hline P0 & - & - & $206 \pm 3.22$ & 31 & 2.99 & 97 & 4.21 \\
\hline P1 & 200 & 1200 & $312 \pm 6.03$ & 34 & 3.43 & 99 & 4.45 \\
\hline P2 & 400 & 1200 & $320 \pm 9.01$ & 32 & 4.21 & 97 & 6.34 \\
\hline P3 & 1000 & 1200 & $346 \pm 6.02$ & 36 & 3.23 & 97 & 5.67 \\
\hline P4 & 1200 & 1200 & $307 \pm 6.04$ & 35 & 2.98 & 96 & 4.21 \\
\hline P5 & 600 & 1200 & $317 \pm 5.01$ & 34 & 3.45 & 98 & 4.26 \\
\hline P6 & 800 & 1200 & $366 \pm 7.11$ & 36 & 3.51 & 99 & 5.57 \\
\hline \multirow[t]{2}{*}{ Phase Two } & \multicolumn{7}{|c|}{ Stable coarse shell against rotated corrugated roller $(\sim 400 \mathrm{rpm})$} \\
\hline & $\begin{array}{l}\text { Biomass load } \\
\left(\mathrm{kg} \text { grass } / \mathrm{m}^{2}\right)\end{array}$ & & $\begin{array}{l}\text { CH4 yield } \\
\text { (mL/g VS) }\end{array}$ & $\begin{array}{l}\mathrm{R}_{\max } \\
(\mathrm{mL} / \mathrm{g} \\
\mathrm{VS} / \mathrm{d})\end{array}$ & $\chi d$ & $\mathrm{R}^{2}(\%)$ & RMSE \\
\hline Q0 & - & & $206 \pm 3.22$ & 32 & 1.78 & 96 & 10.31 \\
\hline Q1 & 1.32 & & $387 \pm 4.05$ & 27 & 2.04 & 97 & 9.24 \\
\hline Q2 & 0.95 & & $366 \pm 8.10$ & 32 & 1.67 & 98 & 11.25 \\
\hline Q3 & 1.21 & & $426 \pm 6.01$ & 40 & 1.74 & 99 & 8.71 \\
\hline Q4 & 1.12 & & $377 \pm 6.00$ & 36 & 1.83 & 95 & 12.34 \\
\hline Q5 & 0.88 & & $367 \pm 7.11$ & 34 & 1.69 & 97 & 11.80 \\
\hline Q6 & 0.76 & & $\begin{array}{l}468 \pm 12 .- \\
01\end{array}$ & 28 & 1.58 & 98 & 9.82 \\
\hline
\end{tabular}

Note: $\mathrm{P}_{0}$ and $\mathrm{Q}_{0}=$ Untreated samples at both phases; $\mathrm{P}_{1}$ to $\mathrm{P}_{6}$ and $\mathrm{Q}_{1}$ to $\mathrm{Q}_{6}=$ mechanically pretreated biomass at both phases; $\mathrm{Rmax}=$ maximum $\mathrm{CH}_{4}$ production rate; $\chi=$ lag phase; $\mathrm{R}^{2}=$ coefficient of determination; RMSE $=$ root mean square error.

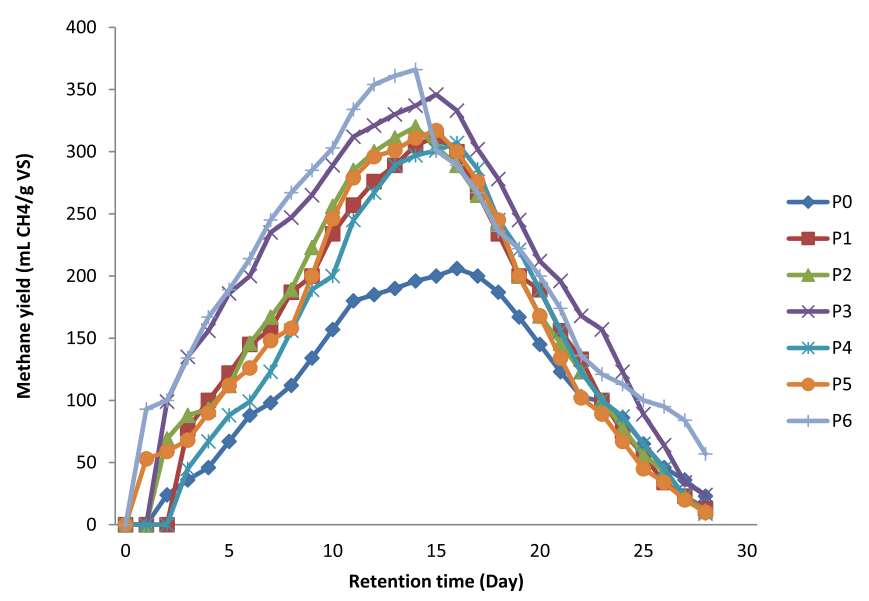

Fig. 1. This figure shows the cumulative methane yield per kilogram of volatile solids for the phase 1 of mechanical pretreatment of the lignocelluloses.

In this study, there were some difficulties in the biomass flow through the used plastic roller majorly due to the size. There is possibility of improving this situation by operating the machine at moderate rotating speed so as to avoid equipment blockade and to apply the demanding shearing forces more efficiently. Mechanical pretreatment in this first phase did not only slightly increase the yield of methane for all biomass used (Fig. 1) but also influenced the kinetic parameters by decreasing the rate limiting phenomenon usually encountered during the hydrolysis stage of anaerobic digestion since the structural components of the biomass have been disrupted by the actions of the rotating brush. Therefore, the used Gompertz model as modified ensured the increase in the rate of digestion during the anaerobic digestion for each of the biomass as carried out in this study. In a previous study on the full scale mechanical pretreatment of lignocellulosic biomass, Tsapekos et al. (2017a) reported the significant reduction of lagging 
during the hydrolysis stage of digestion process. The use of this type of model that reduced the lagging period during digestion has been proposed as appropriate and efficient for the estimation of process parameters during bioprocessing (Kafle and Chen, 2016). In order to evaluate the efficiency of the model, parameters such as the $\mathrm{R}^{2}$ and RMSE were used. In all, there are high $\mathrm{R}^{2}$ values with corresponding low error values. This shows that the model is reliable and accurate in predicting the methane yield. Values similar to these have been reported in the past (Raju et al., 2011).

The second phase of the mechanical pretreatment was carried out so as to further study the biodegradability of the lignocelluloses by using the same machine but with modifications i.e. replacement of the earlier used plastic brush roller with a coarse corrugated roller. This was necessitated by the need to apply more shearing forces with the aid of mesh gratings of coarse steel to bring about the desired changes to the structures of the lignocellulosic biomass as previously demonstrated forces using (Tsapekos et al., 2015). In this case, only one rotating speed ( $\sim 400 \mathrm{rpm})$ was used since the first BMP test and the subsequent anaerobic digestion could not establish a direct correlation between biomass' biodegradability and the speed of the used rotating roller brush. In this second phase, the anaerobic digestion carried out showed a significant $(\mathrm{p}<0.05)$ improvement of the process via the use of the modified pretreatment which is characterized by biogas yield increase by $13-22 \%$ across all digestions (Fig. 2 ).

The loading of biomass into the machine was done at different loading in order to evaluate the possible effect loading variability on their biodegradability. The results however showed that no significant ( $p>0.05$ ) effect of variation in biomass loading on the biodegradability of all the biomass used in this study especially in terms of methane yield increase and shortening of lagging during hydrolysis stage of digestion. Therefore, the efficiency of the mechanical pretreatment was not affected by the biomass loading capacity. This also infers that same level of efficiency could be achieved in practical real-life situation in which large quantity of biomass is handled without any means of optimization.

Tsapekos et al. (2017a) has earlier reported such large scale application of mechanical pretreatment with similar apparatus used in this study have been carried out on lignocellulosic biomass with the resulting effect of structural degradation and up to $20 \%$ methane yield enhancement while other researchers have even reported up to $62 \%$ improvement in the yield of methane by applying mechanical-based pretreatments to different lignocellulosic biomass (Rodriguez et al.,

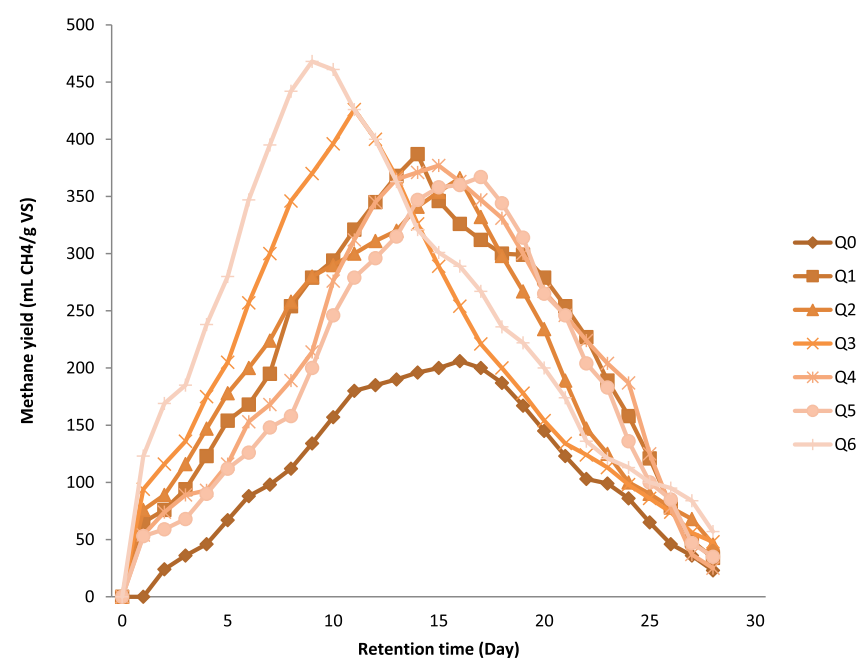

Fig. 2. This figure shows the cumulative methane yield per kilogram of volatile solids for the phase 2 of mechanical pretreatment of the lignocelluloses. Note: $\mathrm{P}_{0}$ and $\mathrm{Q}_{0}=$ Untreated samples at both phases. $\mathrm{P}_{1}$ to $\mathrm{P}_{6}$ and $\mathrm{Q}_{1}$ to $\mathrm{Q}_{6}=$ mechanically pretreated biomass at both phases.
2017). In a recent study, Tsapekos et al. (2017b) carried out the assessment of the balance between produced biogas via mechanical pretreatment and the energy requirement of the machine. They reported an overall improvement in the sustainability of the anaerobic digestion using grass-based biomass with the use of a very efficient full-scale machine. Overall, mechanical pretreatment as shown in this study is an environmentally friendly approach to manage different biomass and diverse waste streams since it has the capacity to cause structural damage to the biomass thereby increasing the surface area for microbial attack in the digesters (Tedesco et al., 2014).

Each biomass showed different rate of methane generation (Rmax) as well as the date when the maximum yield was achieved ( $\mu$ max) which was highest in the digestion of pretreated Chromolaena odorata. It was however not possible to directly draw a relationship between the loading of biomass and kinetic parameters majorly due to heterogeneity in each biomass' variety, growth condition and changes that took place from harvesting time through to the time ensiling and use for biogas generation. Similar observations have been reported (Kreuger et al., 2011; Molinuevo-Salces et al., 2013).

\subsection{Correlation between biomass' chemical composition and methane potential}

As shown in Table 1, the biomass used in this study possesses different chemical characteristics and their respective methane potentials are also shown in the table. Considering the BMP values, there exist wide gaps between the values which range between 200 and $468 \mathrm{~mL} / \mathrm{g}$ VS. It has been previously opined that datasets with wide range of values such as obtained in this study are suitable for drawing a correlation between the chemical compositions of lignocellulosic biomass and their subsequent methane potentials (Raju et al., 2011; Dandikas et al., 2018). Since the values obtained for the $\mathrm{C} / \mathrm{N}$ ratios did not follow normal distribution, this parameter was not used in the mathematical regression analyses. Two methods were used in the mathematical regression analyses used in this study. First, a single linear regression was employed with the most important structural component i.e. lignin with fairly high calibration statistics as shown below:

$\mathrm{CH}_{4}$ yield $(\mathrm{mL} / \mathrm{g}$ VS $)=506.63-7.56 \times \operatorname{Lignin}(\mathrm{g} / 100 \mathrm{~g} \mathrm{VS})$

The $\mathrm{R}^{2}$ value obtained in this model was 0.55 , the RMSE was $32 \mathrm{~mL} /$ $\mathrm{g}$ VS while the NRMSE was $17 \%$. As seen here, the simple linear regression model used in this study which considered the use of biomass chemical composition did not give high estimation accuracy as expected but only serve as a time effective prediction model. Such observations have been reported by previous researchers who instead have proposed the use of multiple linear regression models in order to achieve higher prediction accuracy (Dandikas et al., 2014; Kafle and Chen, 2016; Edwiges et al., 2018). Based on these suggestions, a multiple regression model was employed in this study with lignin, arabinan and protein compositions as the regressors while the yield of methane was used as the regressand since the composition of cellulose and hemicellulose are considered insignificant $(\mathrm{p}<0.05)$ for the model (Dandikas et al., 2015). The model is as shown below:

$$
\begin{aligned}
\mathrm{CH}_{4} \text { yield }(\mathrm{mL} / \mathrm{g} \mathrm{VS})= & 281.66+15.72 \times \operatorname{Arabinan}(\mathrm{g} / 100 \mathrm{~g} \mathrm{VS}) \\
& --3.50 \times \operatorname{Lignin}(\mathrm{g} / 100 \mathrm{~g} \mathrm{VS}) \\
& +28.46 \times \operatorname{Protein}(\mathrm{g} / 100 \mathrm{~g} \mathrm{VS})
\end{aligned}
$$

By using this multiple regression, there was improvement in the accuracy of prediction over the single linear model. The value of the $\mathrm{R}^{2}$ increased to 0.63 , RMSE was $22 \mathrm{~mL} / \mathrm{gVS}$ while the NRMSE was $13 \%$. After this, the normal distribution of the residual was examined using the Kolmogorov-Smirnov test in which the null hypothesis was accepted.

The method of correlating biomass chemical composition with their potentials has been reported in some studies with different results. One 
of such studies was carried out by Dandikas et al. (2015) using lignin, hemicellulose and protein as variables in a multiple linear regression model that resulted in a $\mathrm{R}^{2}$ value of 0.70 which is even higher in accuracy than the result of the present study due to the use of large number and varieties of grass whose harvesting were done at different phases of growth which must have had a significant impact on the parameters such as the lignin composition. Also, in Herrmann et al. (2016), composition of lignin, protein, butyric acid and alcohols were used as regressors and a slightly high prediction accuracy was achieved with $\mathrm{R}^{2}$ of 0.64 and RMSE of $27 \mathrm{~mL} / \mathrm{g}$ VS which can also be attributed to the use of a large set of data drawn from many plant species.

There is more similarity between the result of this current study and that of Herrmann et al. (2016) in that only ensilaged biomass were used unlike other studies that employed different lignocellulosic biomass with heterogeneous dataset and which imparted on the prediction accuracy of the models. This equally implies that the chemical composition of a particular lignocellulosic biomass is a sure factor in determining its methane potential and to predict its biodegradability.

\subsection{Microbial composition and volatile fatty acids (VFAs) dynamics}

During the anaerobic digestion in all four different experiments, several microorganisms were isolated and identified by the molecular methods used. These include aerobes such as Bacillus pantothenticus, Bacillus licheniformis, Bacillus stearothermophilus, Serratia ficaria, Serratia plymuthica and Proteus vulgaris. Identified anaerobes include Clostridium clostridioforme, Fusobacterium mortiferum and Porphyromonas assacharolyticum while the methanogen include members of the genera Methanobacteriales, Methanosaetaceae, Methanomicrobiales and Methanosarcinaceae. The presence of high microbial population and activities in an anaerobic digester usually leads to the accumulation of VFAs because the microorganisms produce a number of intermediate acids that are well known to cause inhibition of the digestion process. However, accumulation of these VFAs is largely dependent on the balance between their production and consumption rates by the digesters bacterial community. In the current study, acetate and propionate are the predominant VFAs which were only slightly accumulated except at the middle of the digestion process i.e. between the 12th 16th days when their concentrations reached the peak in all four digestions. This is an indication of imbalance between the first two stages combined i.e. hydrolysis-acidogenesis and the last two stages combined i.e. acetogenesis-methanogenesis (Riggio et al., 2017).

\subsection{Energy balance}

The combined heat and power (CHP) system was employed in the computation of the balance of energy with thermal and electrical efficiencies of 50\% and 35\% (Dahunsi et al., 2017a) (Table 4). The thermal energy required for raising the temperature of $35 \mathrm{~g} \mathrm{TS} \mathrm{L}^{-1}$ mixture of each of the biomass (Pennisetum purpureum (Monado), Pennisetum purpureum (King grass), Tithonia diversifolia, Tithonia rotundifolia, Tithonia tubiformis and Chromolaena odorata) and water from $25^{\circ} \mathrm{C}$ to $55^{\circ} \mathrm{C}$ was therefore determined taking the specific heat of water to be $4.18 \mathrm{~kJ} \mathrm{~kg}^{-1}{ }^{\circ} \mathrm{C}^{-1}$ neglecting heat loss (Dahunsi et al., 2017a,c). For all the biomass, the $668,696,1,212,798,772$ and $1,282 \mathrm{kWh} \mathrm{t}^{-1}$ TS thermal energy gain was higher than the $346,346,323,323,322$ and $335 \mathrm{kWh} \mathrm{t}^{-1}$ TS thermal energy that was initially required to carry out the mechanical pretreatment for each biomass thus giving a net thermal energy of 322, 350, 889, 475, 450 and $947 \mathrm{kWh} \mathrm{t}^{-1}$ TS. The highest net thermal energy was obtained from the digestion of pretreated Chromolaena odorata while the lowest was from pretreated Pennisetum purpureum (Morado). The possibility is there that this net energy can be increased via the use of heat exchanger during the pretreatment or for heating of the digester. Heat exchangers have been previously employed to increase the recovery of thermal energy up to about $80 \%$ (Zabranska et al., 2006). Perhaps, full integration of thermal energy is

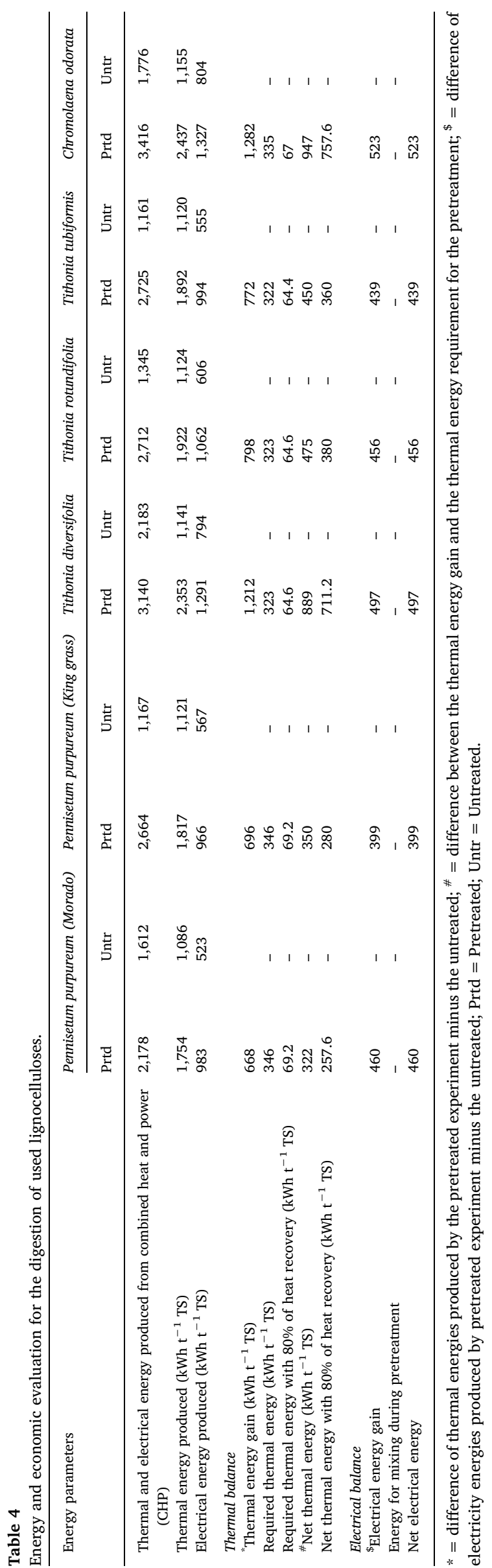


another prominent method for assessing the economic feasibility in this study as earlier reported (Perez-Elvira and Fdz-Polanco, 2012).

In carrying out the assessment of electrical energy, an account was only taken for the energy consumed during the mechanical grinding of each biomass following earlier submissions (Menardo et al., 2012; Zhao et al., 2018). For all the biomass, the net electrical energy of 460, 399, 497, 456, 439 and $523 \mathrm{kWh} \mathrm{t}^{-1}$ TS were obtained. This further confirms the economic feasibility of using mechanical pretreatment. The net thermal and electrical energies obtained can be sold directly to consumers or injected into the energy grid following standard environmental and governmental rules.

\section{Conclusions}

In this study, the application of mechanical pretreatment in two different phases enhanced the breakdown of structural materials in all the used biomass which was characterized by reduction of the lagging time during anaerobic digestion and the subsequent increase in methane yield up to $22 \%$. However, the different loading rate of biomass had no effect on the overall methane yield increase. Both the single and multiple linear regressions models were used in order to correlate the chemical composition of the biomass with their methane potentials and a fairly high correlation was obtained. Further application of mechanical pretreatments is recommended.

\section{Acknowledgments}

The author appreciates the efforts of the technical staffs in the Environmental Engineering Laboratory of Landmark University, OmuAran, Nigeria.

\section{Funding source}

This research received funding from the Ton Duc Thang University, Ho Chi Minh City, Vietnam.

\section{Conflict of interest}

Author declares no conflict of interest whatsoever.

\section{References}

APHA, 2012. Standard Methods for the Examination of Water and Wastewater. American Public Health Association, Washington, DC, USA.

Bazoti, S.F., Golunski, S., Pereira, S.D., Scapini, T., Barrilli, É.T., Alex, M.D., Barros, K.O., Rosa, C.A., Stambuk, B.U., Alves, S.L., Valério, A., de Oliveira, D., Treichel, H., 2017. Second-generation ethanol from non-detoxified sugarcane hydrolysate by a rotting wood isolated yeast strain. Bioresour. Technol. 244, 582-587.

Boon, N., De Windt, W., Verstraete, W., Top, E.M., 2002. Evaluation of nested PCR-DGGE (denaturing gradient gel electrophoresis) with group-specific 16S rRNA primers for the analysis of bacterial communities from different wastewater treatment plants. FEMS Microbiol. Ecol. 39, 101-112.

Boscaro, D., Pezzuolo, A., Grigolato, S., Cavalli, R., Marinello, F., Sartori, L., 2015. Preliminary analysis on mowing and harvesting grass along riverbanks for the supply of anaerobic digestion plants in north-eastern Italy. J. Agric. Eng. 46, 100-104.

Cai, D., Li, P., Chen, C., Wang, Y., Hu, S., Cui, C., Qin, P., Tan, T., 2016. Effect of chemical pretreatments on corn stalk bagasse as immobilizing carrier of Clostridium acetobutylicum in the performance of a fermentation-pervaporation coupled system. Bioresour. Technol. 220, 68-75.

Carrere, H., Antonopoulou, G., Affes, R., Passos, F., Battimelli, A., Lyberatos, G., Ferrer, I., 2015. Review of feedstock pretreatment strategies for improved anaerobic digestion: from lab-scale research to full-scale application. Bioresource Technol. 199, 386-397.

Charnier, C., Latrille, E., Jimenez, J., Lemoine, M., Boulet, J.C., Miroux, J., Steyer, J.-P., 2016. Fast characterization of solid organic waste content with near infrared spectroscopy in anaerobic digestion. Waste Manage. 59, 140-148.

Dahunsi, S.O., Oranusi, S., Owolabi, J.B., Efeovbokhan, V.E., 2017f. Synergy of Siam weed (Chromolaena odorata) and poultry manure for energy generation: effects of pretreatment methods, modelling and process optimization. Bioresour. Technol. 225, 409-417.

Dahunsi, S.O., Oranusi, S., Efeovbokhan, V.E., 2017d. Optimization of pretreatment, process performance, Mass and Energy balance in the anaerobic digestion of Arachis hypogaea (Peanut) hull. Energy Conv. Manage. 139, 260-275.

Dahunsi, S.O., Oranusi, S., Efeovbokhan, V.E., 2017e. Pretreatment optimization, Process control, Mass and Energy balances and Economics of anaerobic co-digestion of Arachis hypogaea (Peanut) hull and poultry manure. Bioresour. Technol. 241, 454-464.

Dahunsi, S.O., Oranusi, S., Efeovbokhan, V.E., 2017b. Bioconversion of Tithonia diversifolia (Mexican Sunflower) and poultry droppings for energy generation: optimization, mass and energy balances, and economic benefits. Energy Fuels 31, 5145-5157.

Dahunsi, S.O., Oranusi, S., Efeovbokhan, V.E., 2017a. Anaerobic mono-digestion of Tithonia diversifolia (Wild Mexican sunflower). Energy Convers. Manage. 148, $128-145$.

Dahunsi, S.O., Oranusi, S., Efeovbokhan, V.E., 2017c. Cleaner energy for cleaner production: modeling and optimization of biogas generation from Carica papayas (Pawpaw) fruit peels. J. Clean. Prod. 156, 19-29.

Dahunsi, S.O., Oranusi, S., Efeovbokhan, V.E., Olayanju, A., Zahedi, S., Ojediran, J.O., Izebere, J.O., Aladegboye, O.J., 2018a. Anaerobic conversion of Chromolaena odorata (Siam weed) to biogas. Energy Rep. 4, 691-700.

Dahunsi, S.O., Oranusi, S., Efeovbokhan, V.E., Zahedi, S., Ojediran, J.O., Olayanju, A., Oluyori, A.P., Adekanye, T.A., Izebere, J.O., Enyinnaya, M., 2018b. Biochemical conversion of fruit rind of Telfairia occidentalis (Fluted Pumpkin) and Poultry Manure. Energy Sources (Part A) Utiliz. Environ. Effects. 40 (23), 2799-2811.

Dandikas, V., Heuwinkel, H., Lichti, F., Drewes, J.E., Koch, K., 2014. Correlation between biogas yield and chemical composition of energy crops. Bioresour. Technol. 174, 316-320.

Dandikas, V., Heuwinkel, H., Lichti, F., Drewes, J.E., Koch, K., 2015. Correlation between biogas yield and chemical composition of Grassland Plant Species. Energy Fuels 29, 7221-7229.

Dandikas, V., Heuwinkel, H., Lichti, F., Eckl, T., Drewes, J.E., Koch, K., 2018. Correlation between hydrolysis rate constant and chemical composition of energy crops. Renew. Energy 118, 34-42.

Desloover, J., De Vrieze, J., de Vijver, M.V., Mortelmans, J., Rozendal, R., 2015. Electrochemical nutrient recovery enables ammonia toxicity control and biogas desulfurization in anaerobic digestion. Envion. Sci. Technol. 49, 948-955.

Edwiges, T., Frare, L., Mayer, B., Lins, L., Mi Triolo, J., Flotats, X., de Mendonça Costa, M.S.S., 2018. Influence of chemical composition on biochemical methane potential of fruit and vegetable waste. Waste Manage. 71, 618-625.

Faostat, 2016. Food and Agriculture Organization of the United Nations - Statistical Databases [WWW Document]. URL < http://faostat.fao.org $>$. (Accessed 5 January 2016).

Fitamo, T., Triolo, J.M., Boldrin, A., Scheutz, C., 2017. Rapid biochemical methane potential prediction of urban organic waste with near-infrared reflectance spectroscopy. Water Res. 119, 242-251.

Hayashi, K., Ono, K., Kajiura, M., Sudo, S., Yonemura, S., Fushimi, A., Saitoh, K., Fujitani, Y., Tanabe, K., 2014. Trace gas and particle emissions from open burning of three cereal crop residues: increase in residue moistness enhances emissions of carbon monoxide, methane, and particulate organic carbon. Atmos. Environ. 95, 36-44.

Herrmann, C., Prochnow, A., Heiermann, M., Idler, C., 2012. Particle size reduction during harvesting of crop feedstock for biogas production II: effects on energy balance, greenhouse gas emissions and profitability. Bioenergy Res. 5, 937-948.

Herrmann, C., Idler, C., Heiermann, M., 2016. Biogas crops grown in energy crop rotations: linking chemical composition and methane production characteristics. Bioresour. Technol. 206, 23-35.

Kafle, G.K., Chen, L., 2016. Comparison on batch anaerobic digestion of five different livestock manures and prediction of biochemical methane potential (BMP) using different statistical models. Waste Manage. 48, 492-502.

Katukuri, N.R., Fu, S., He, S., Xu, X., Yuan, X., Yang, Z., Guo, R.-B., 2017. Enhanced methane production of Miscanthus floridulus by hydrogen peroxide pretreatment. Fuel 199, 562-566.

Kreuger, E., Prade, T., Escobar, F., Svensson, S.-E., Englund, J.E., Björnsson, L., 2011. Anaerobic digestion of industrial hemp - effect of harvest time on methane energy yield per hectare. Biomass Bioenergy 35, 893-900.

Li, P., Cai, D., Luo, Z., Qin, P., Chen, C., Wang, Y., Zhang, C., Wang, Z., Tan, T., 2016 Effect of acid pretreatment on different parts of corn stalk for second generation ethanol production. Bioresour. Technol. 206, 86-92.

Menardo, S., Airoldi, G., Balsari, P., 2012. The effect of particle size and thermal pretreatment on the methane yield of four agricultural by-products. Bioresour. Technol. 104, 708-714.

Molinuevo-Salces, B., Larsen, S.U., Ahring, B.K., Uellendahl, H., 2013. Biogas production from catch crops: evaluation of biomass yield and methane potential of catch crops in organic crop rotations. Biomass Bioenergy 59, 285-292.

Panjičko, M., Zupančič, G.D., Fanedl, L., Marinšek Logar, R., Tišma, M., Zelić, B., 2017. Biogas production from brewery spent grain as a mono-substrate in a two-stage process composed of solid-state anaerobic digestion and granular biomass reactors. $\mathrm{J}$ Clean. Prod. 166, 519-529.

Perez-Elvira, S.I., Fdz-Polanco, F., 2012. Continuous thermal hydrolysis and anaerobic digestion of sludge: energy integration study. Water Sci. Technol. 65 (10), 1839-1846.

Planinić, M., Zelić, B., Čubel, I., Bucić-Kojić, A., Tišma, M., 2016. Corn forage biological pretreatment by Trametes versicolor in a tray bioreactor. Waste Manage. Res. 34, 802-809.

Raju, C.S., Ward, A.J., Nielsen, L., Møller, H.B., 2011. Comparison of near infra-red spectroscopy, neutral detergent fibre assay and in-vitro organic matter digestibility assay for rapid determination of the biochemical methane potential of meadow grasses. Bioresour. Technol. 102, 7835-7839.

Riggio, S., Torrijos, M., Debord, R., Esposito, G., van Hullebusch, E.D., Steyer, J.P., 2017. Mesophilic anaerobic digestion of several types of spent livestock bedding in a batch leach-bed reactor: substrate characterization and process performance. Waste Manage. 9, 129-139. 
Rodriguez, C., Alaswad, A., Benyounis, K.Y., Olabi, A.G., 2017. Pretreatment techniques used in biogas production from grass. Renew. Sustain. Energy Rev. 68, 1193-12041.

Sluiter, A., Hames, B., Ruiz, R., Scarlata, C., Sluiter, J., Templeton, D., 2008. Determination of Ash in Biomass. Laboratory Analytical Procedures (LAP). Natl. Renew Energy Lab. 1-8 Report No. TP-510-42622.

Sluiter, A., Hames, B., Ruiz, R., Scarlata, C., Sluiter, J., Templeton, D., Crocker, D., 2012. Determination of Structural Carbohydrates and Lignin in Biomass. Laboratory Analytical Procedures (LAP). Natl. Renew Energy Lab. 1-18 Report No. TP-51042618.

Tedesco, S., Mac Lochlainn, D., Olabi, A.G., 2014. Particle size reduction optimization of Laminaria spp. biomass for enhanced methane production. Energy 76, 857-862.

Tsapekos, P., Kougias, P.G., Angelidaki, I., 2015. Biogas production from ensiled meadow grass; effect of mechanical pretreatments and rapid determination of substrate biodegradability via physicochemical methods. Bioresour. Technol. 182, 329-335.

Tsapekos, P., Kougias, P.G., Egelund, H., Larsen, U., Pedersen, J., Trénel, P., Angelidaki, I., 2017a. Mechanical pretreatment at harvesting increases the bioenergy output from marginal land grasses. Renew. Energy 111, 914-921.

Tsapekos, P., Kougias, P.G., Egelund, H., Larsen, U., Pedersen, J., Trénel, P., Angelidaki, I., 2017b. Improving the energy balance of grass-based anaerobic digestion through harvesting optimisation. Anaerobe 46, 131-137.

Tsapekos, P., Kougias, P.G., Angelidaki, I., 2018. Mechanical pretreatment for increased biogas production from lignocellulosic biomass; predicting the methane yield from structural plant components. Waste Manage. 78, 903-910.

Venturin, B., Camargo, A.F., Scapini, T., Mulinari, J., Bonatto, C., Bazoti, S., Siqueira, D.P., Colla, L.M., Alves Jr., S.L., Bender, J.P., Steinmetz, R.L.R., Kunze, A., Fongaro, G., Treichel, H., 2018. Effect of pretreatments on corn stalk chemical properties for biogas production purposes. Bioresour. Technol. 266, 116-124.

Vilchez-Vargas, R., Geffers, R., Suarez-Diez, M., Conte, I., Waliczek, A., Kaser, V.S. Kralova, M., Junca, H., Pieper, D.H., 2013. Analysis of the microbial gene landscape and transcriptome for aromatic pollutants and alkane degradation using a novel internally calibrated microarray system. Environ. Microbiol. 15, 1016-1039.

Zabranska, J., Dohanyos, M., Jenicek, P., Kutil, J., 2006. Disintegration of excess activated sludge - evaluation and experience of full-scale applications. Water Sci. Technol. 53, 229-236.

Zhao, X., Luo, K., Zhang, Y., Zheng, Z., Cai, Y., 2018. Improving the methane yield of maize straw: focus on the effects of pretreatment with fungi and their secreted enzymes combined with sodium hydroxide. Bioresour. Technol. 250, 204-213. 